\title{
Effect of Supplementation Organic Acid Salt and Probiotics Derived from Silage of Kumpai Tembaga Grass on Quality Carcass and Meat of Pegagan Duck
}

\author{
Meisji Liana Sari, S. Sandi*, F. Yosi, A.N.T. Pratama
}

Department of Animal Science, Faculty of Agriculture, University of Sriwijaya, Palembang, South Sumatera, Indonesia.

\begin{abstract}
The aim of this study was to determine the supplement effect of organic acid salt and probiotics derived from silage of kumpai tembaga grass on yield Carcass and meat of pegagan duck. The research was conducted in 4 weeks. The sample used was 72 Pegagan ducks at one-day-old. The treatments were P0 (ration), P1 (ration $+0.02 \%$ probiotic), $\mathrm{P} 2$ (ration $+0.2 \%$ organic acid salt), $\mathrm{P} 3$ (ration $+0.1 \%$ tetracycline), $\mathrm{P} 4$ (ration $+0.02 \%$ probiotic $+0.2 \%$ organic acid salt), P5 (ration $+0.02 \%$ probiotic $+0.2 \%$ organic acid salt $+0.1 \%$ tetracycline). The observed variables were live weight, carcass weight, and percentage carcass slice (thighs, breast, back, wings), $\mathrm{pH}$, water holding capacity, shrinkage and meat tenderness. The results showed that supplementation of organic acid salts and probiotics had no significant effect $(\mathrm{P}>$ 0.05 ) to live weight, carcass and carcass percentage, carcass slice (thighs, breast, back and wings), $\mathrm{pH}$, water holding capacity, shrinkage and meat tenderness. However, the variables carcas weight and percentage had a tendency increase on supplementation compared to the control treatment. In conclusion, organic acid salts and probiotic treatments did not affect carcass and meat quality but showed a tendency to increase carcass weight and the percentage of carcass and commercial breast slices from Pegagan duck.
\end{abstract}

Keywords | Carcass, Kumpai tembaga grass silage, Meat quality, Organic acid salt, Pegagan duck

Received | July 01, 2019; Accepted | November 12, 2019; Published | November 26, 2019

*Correspondence | S. Sandi, Department of Animal Science, Faculty of Agriculture, University of Sriwijaya, Palembang, South Sumatera, Indonesia; Email: sofiasandi_nasir@yahoo.com

Citation | Sari ML, Sandi S, Yosi F, Pratama ANT (2019). Effect of supplementation organic acid salt and probiotics derived from silage of kumpai tembaga grass on quality carcass and meat of pegagan duck. Adv. Anim. Vet. Sci. 7(12): 1120-1126.

DOI | http://dx.doi.org/10.17582/journal.aavs/2019/7.12.1120.1126

ISSN (Online) | 2307-8316; ISSN (Print) | 2309-3331

Copyright (c) 2019 Sari et al. This is an open access article distributed under the Creative Commons Attribution License, which permits unrestricted use, distribution, and reproduction in any medium, provided the original work is properly cited.

\section{INTRODUCTION}

$\mathrm{D}$ uck carcass and meat are one of the poultry products widely consumed due to it cheapness compare to cow meat. The increase of carcass and meat production can be achieved by improving ration quality fed in an optimum way. In addition to nutrition intake, an additional supplement can be added into ration to enhance animal growth as well as carcass and meat in form of probiotic and organic acid salt. The secondary metabolite produced from silage forage swamp particularly kumpai tembaga grass has the potential use as probiotic and organic acid. According to Sandi et al. (2017), kumpai tembaga silage provides a larger amount of lactic acid and its corresponding bacteria compare to swamp legume silage and silage of grass combined with the legume.
Probiotic is a microbe lives within its host and gives positive influence in enhancing microorganism balance in the digestive tract (Fuller, 1989). It is well known that probiotic provides good influence on livestock performance particularly on increasing the intestine ability to digest ration by improving microflora balance. As the performance of digestive tract increased in absorbing nutrient especially protein, the carcass and meat production will also increase. Sukirmansyah et al. (2016) reported the utilization of probiotic fermentation ration shows no negative effect to the carcass weight, in fact, it was able to increase carcass and slice percentage of Pecking duck in 8 weeks of age.

Organic acid acts as an acidifier to create the acidic condition in the small intestine and provide a good environment for Lactobacillus growth and other non- 
pathogenic microbes but prevent the growth of Escherichia coli, Salmonella, and other pathogenic microbes. The better acidifier performance in the small intestine support the activity and digestive enzyme function which enhance ration consumption, increase nutrient absorption, reduce ammonia production and microbial metabolite product which inhibit growth. The organic acid intake as livestock ration is preferred in form of an organic acid salt which can be obtained by mixing organic acid with a base to produce crystal salt. The salt has minimum evaporation as well as decrease the organic acid metabolism within the upper digestive tract of poultry (Negara, 2009). AbdelFattah et al. (2008) proved that the addition of organic acid (acidifier) into drinking water or broiler's ration increase the absorption by improving digestive enzyme function particularly the one which absorbed fiber and protein. The aim of this research was to evaluate the effect of organic acid salt and probiotic from silage of kumpai tembaga grass intake to the quality of carcass and physical meat of Pegagan duck.

\section{MATERIALS AND METHODS}

\section{Animal, Diet, Experimental Design and sampling} One-day-old Pegagagan Duck ( $=72)$ with weight about 26-53 g were randomly selected regardless of sex and reared in six groups randomly allocated with 4 replications each replicating there were 3 ducks for an 4-week period in animal husbandry science experiments from Sriwijaya University, Indonesia. Observation conducted at the end of this study. For every treatment and replication, 2 ducks were taken to measure its carcass and meat quality.

Research variables were carcass quality which includes cut weight, carcass weight, carcass percentage, carcass slices weight (Soeparno, 2005). The physical quality of meat was meat $\mathrm{pH}$ (Apriyanto et al., 1989), water holding capacity, shrinkage and meat tenderness (Hartono, 2013). The design used in this study was a completely randomized design with 6 treatments and 4 replications which were P0 (basal ration), $\mathrm{P} 1$ (ration + probiotics), $\mathrm{P} 2$ (ration + organic acid salt), P3 (ration + tetracycline), $\mathrm{P} 4$ (+ ratio organic acid salts + probiotics) and $\mathrm{P} 5$ (rations + organic acid salts + probiotics + tetracyclines). Organic acid salts $(0.2 \%)$, tetracyclines $(0.2 \%)$ and probiotics $(0.02 \%)$ are given daily for 4 weeks by mixing them into rations.

Ration and drinking water were given ad-libitum consumption throughout the period. The experimental diets were formulated to meet the nutritional requirements for poultry according to National Research Council (NRC, 1994). Starter and replace grower with the finisher diets were fed from days 1 to 21 and from days 22 to 35 , respectively. The ration composition and nutrients content were made as displayed in Table 1.
Table 1: Composition and nutrients content of basal ration used in the research.

\begin{tabular}{lll} 
Feed Ingredients & Total(\%) & \\
& Starter phase & Finisher phase \\
Corn powder & 53.50 & 67.00 \\
Bran & 3.00 & 5.00 \\
Concentrate & 43.00 & 27.00 \\
Premix & 0.50 & 1.00 \\
Nutrients content & & \\
EM (kcal EM/Kg) & 2916.43 & 3012.55 \\
Crude Protein (\%) & 22.10 & 17.09 \\
Crude Fiber (\%) & 6.30 & 5.65 \\
Extract Ether (\%) & 0.86 & 0.54 \\
Ca (\%) & 3.45 & 2.18 \\
P (\%) & 0.40 & 0.38 \\
\hline
\end{tabular}

Note: Nutrition need according to NRC (1994).

\section{Preparation of Organic Acid Salt}

Organic acid salt was made through acid-base neutralization reaction. The acid was obtained from the supernatant of silage complete ration liquid whereas base was $\mathrm{ZnO}$ (12.5\%). Supernatant from each silage liquid was reacted with a base at $\mathrm{pH} 12$ and then left for 24 hours in room temperature. Salt precipitated was separated from the supernatant by centrifugation (3000 rpm for 15 minutes). The precipitate was dried in an oven $\left(60{ }^{\circ} \mathrm{C}\right)$ for 3 days and grinded to obtained fine particles (Negara, 2009).

\section{Preparation of Probiotic}

Probiotic used in this research was collected from lactic acid bacteria isolated from silage of kumpai tembaga grass. The lactic acid bacteria isolate was cultured in MRSB (deMannRogosa Sharpe Agar in form of liquid/broth) and then incubated for 48 hours. The bacteria culture was centrifuged in $3000 \mathrm{rpm}$ for 15 minutes to obtain a substrate from the supernatant. The substrate was mixed with milk skim and maltodextrin 5\% (w/w). The next step was dried spray at 160 to $180^{\circ} \mathrm{C}$. The result of this process was powder product ready to add in ration (Bregni et al., 2000).

\section{Statistical analyses}

Data obtained from observations and measurements will be analyzed based on one way anova analysis, if there is a significant difference between treatments then it will be followed by Duncan's Multiple Range Test (Steel and Torrie, 1993).

\section{RESULTS}

Based on the results of data analysis showed that supplementation of organic acid salts and probiotics did not give a significant increase $(P>0.05)$ to carcass and meat 
Table 2: The average of Pegagan duck carcass quality treated by organic acid salt and probiotic.

$\begin{array}{llllllll}\text { code } & \begin{array}{l}\text { Live weight } \\ \text { (Kg) }\end{array} & \begin{array}{l}\text { Carcass } \\ \text { weight } \mathbf{( K g )}\end{array} & \begin{array}{l}\text { Carcass per- } \\ \text { centage (\%) }\end{array} & \begin{array}{l}\text { Thigh percent- } \\ \text { age (\%) }\end{array} & \begin{array}{l}\text { Breast percent- } \\ \text { age (\%) }\end{array} & \begin{array}{l}\text { Back percentage Wing percent- } \\ \text { (\%) }\end{array} & \begin{array}{l}\text { Wge (\%) } \\ \text { age }\end{array} \\ \text { P0 } & 1.18 \pm 0.10 & 0.66 \pm 0.03 & 56.67 \pm 3.98 & 24.82 \pm 2.01 & 35.64 \pm 2.41 & 20.08 \pm 0.49 & 16.23 \pm 0.44 \\ \text { P1 } & 1.21 \pm 0.12 & 0.71 \pm 0.09 & 58.93 \pm 5.24 & 27.69 \pm 6.32 & 38.88 \pm 2.57 & 18.55 \pm 1.65 & 17.31 \pm 1.38 \\ \text { P2 } & 1.19 \pm 0.04 & 0.69 \pm 0.04 & 58.12 \pm 2.57 & 24.03 \pm 1.99 & 36.95 \pm 2.04 & 20.19 \pm 1.40 & 15.82 \pm 0.39 \\ \text { P3 } & 1.21 \pm 0.11 & 0.77 \pm 0.08 & 63.67 \pm 2.17 & 24.44 \pm 1.75 & 37.30 \pm 2.29 & 19.62 \pm 0.93 & 16.88 \pm 1.56 \\ \text { P4 } & 1.13 \pm 0.05 & 0.74 \pm 0.12 & 64.75 \pm 8.35 & 23.05 \pm 5.06 & 36.97 \pm 5.28 & 18.64 \pm 3.07 & 16.31 \pm 3.11 \\ \text { P5 } & 1.24 \pm 0.04 & 0.81 \pm 0.02 & 65.56 \pm 2.71 & 24.42 \pm 3.07 & 38.46 \pm 2.05 & 18.15 \pm 1.59 & 16.25 \pm 0.42\end{array}$

Note: P0 (basal ration), P1 (ration + probiotic), P2 (ration + organicacidsalt), P3 (ration + tetracycline), P4 (ratio + organicacidsalt + probiotic) and P5 (ration + organicacidsalt + probiotic + tetracycline) .

quality in pegagan duck. however, the data shows a tedency towards an increase in carcasses of pegagan duck.

\section{Carcass Quality}

The effect of organic acid salt and probiotic product from kumpai tembaga grass silage on carcass quality is shown in Table 2. Analysis of variance shows that organic acid salt and probiotic treatment is not statistically significant $(P>0.05)$ to live weight, carcass weight and percentage of Pegagan duck. The mean values of the treatment group included live weight, carcass weight and carcass percentage ranging from 1.13 to $1.24 \mathrm{Kg}, 0.66$ to $0.81 \mathrm{Kg}$, and 56.67 to $65.56 \%$.

\section{Meat Physical Quality}

The effect of organic acid salt and probiotic product from Kumpai tembaga grass silage on the meat physical quality is shown in Table 3. Analysis of variance result shows no statistically significant difference between the treatment of probiotic and organic acid salt and untreated in term of meat $\mathrm{pH}(\mathrm{P}>0.05)$. The mean value of the meat $\mathrm{pH}$ treatments group ranging from 6.53 to 6.70 , while in the water holding capacity (WHC), shrinkage and tenderness ranging from 41.04 to $43.31 \%, 40.29$ to $41.99 \%$. and 4.83 to $5.44 \mathrm{~N}$.

\section{DISCUSSION}

\section{LIVE WEIGHT}

The value of poultry performance is determined mainly based on live weight, carcass weight, and carcass percentage. Pegagan duck live weight after 4 weeks treatment by probiotic and organic acid salt was between 1.13 and $1.24 \mathrm{~kg}$. This result higher than obtained by Puspani et al. (2016) i.e. $0.95-1.08 \mathrm{~kg}$ which was treated local duck by probiotic supplement into the basal ration, but lower than result reported by Nugraha et al. (2016) i.e. 1.59$1.62 \mathrm{~kg}$ when using citric acid addition as acidifier into male duck ration. The carcass weight and percentage of the Pegagan duck after the treatment given were 0.66-0.81 $\mathrm{Kg}$ and 56.67-65.56\%. This result higher than reported by Sukirmansyah et al. (2016) whom used Peking duck and obtained result $0.83-0.90 \mathrm{~kg}$ and $51.67-54.04 \%$ of carcass weight and percentage respectively. Furthermore, it is showed that probiotic and organic acid salt treatments did not significantly affect the commercial carcass slice percentage (thighs, breast, wing, and back).

Table 3: Average value of meat physical quality of Pegagan duck treated by organic acid salt and probiotic.

\begin{tabular}{lllll}
$\begin{array}{l}\text { Treat- } \\
\text { ment }\end{array}$ & Meat $\mathbf{p H}$ & $\begin{array}{l}\text { Waterholding } \\
\text { capacity }(\mathbf{\%})\end{array}$ & $\begin{array}{l}\text { shrinkage } \\
(\mathbf{\%})\end{array}$ & $\begin{array}{l}\text { Tenderness } \\
(\mathbf{N})\end{array}$ \\
\hline P0 & $6.60 \pm 0.14$ & $42.61 \pm 3.10$ & $41.99 \pm 9.15$ & $5.52 \pm 0.20$ \\
P1 & $6.68 \pm 0.13$ & $41.96 \pm 3.31$ & $41.02 \pm 3.65$ & $5.17 \pm 0.49$ \\
P2 & $6.70 \pm 0.14$ & $43.32 \pm 3.61$ & $40.37 \pm 2.79$ & $5.41 \pm 0.21$ \\
P3 & $6.53 \pm 0.05$ & $42.44 \pm 5.85$ & $41.21 \pm 2.03$ & $5.02 \pm 0.23$ \\
P4 & $6.58 \pm 0.10$ & $41.71 \pm 3.97$ & $40.29 \pm 1.10$ & $5.26 \pm 0.36$ \\
\hline P5 & $6.53 \pm 0.05$ & $41.05 \pm 5.00$ & $41.67 \pm 1.54$ & $5.42 \pm 0.15$ \\
\hline
\end{tabular}

Note: P0 (basal ration), P1 (ration + probiotic), P2 (ration + organicacidsalt), P3 (ration + tetracycline), P4 (ratio + organicacidsalt + probiotic) and P5 (ration + organicacidsalt + probiotic + tetracycline).

The results confirmed that there was no effect of organic acid salts and probiotics between being treated with no treatment of live weight. Sihite and Pakpahan (2015) suggested that probiotics obtained from Streptococcus thermophillus and Bacillus cereus could not increase local duck weight. Research by Natsir and Sjofjan (2008) also confirms that the treatment of organic acids (citric and lactic acid) has no effect on live weight. Furthermore, the authors reason that the absence of influence was due to similar ration composition. Srigandono (1997) described that live weight was affected by the ration consumption as well as its nutrient composition. Sudiyono and Purwatri (2007) added that live weight also affected by ration quality and livestock growth rate. The rate of growth is indicated by an increase in body weight which in turn affect live weight increment. The absence of probiotic and organic acid effect can also cause by insufficient dosage given as reported by Astuti et al. (2015). According to this author, probiotic 
OPEN OACCESS

won't effectively work if it was given in inappropriate dosage. Owings et al. (1990) reviewed that several attempts of probiotic use did not give satisfying result due to some reason i.e. dosage level given and bacterial resistance ability within an extreme condition of the digestive tract and short duration treatment. Soltan (2008) reported the effect of organic acid used in a single dose or in cocktail ration mixture to depend on the organic acid type, original source and its amount given as does with livestock condition and ration composition.

Our findings are similar to Mulyani et al. (2013) who used a different probiotics to produce citric acid compounds, i.e 53.96-62.25\%. Sastroamidjojo (1990) suggested that in general the percentage of carcass can be obtained ranged from 50 to $60 \%$. Sukirmansyah et al. (2016) obtained a similar result that carcass weight and percentage were not affected by fermentation probiotic as well as result reported by Mulyani et al. (2013). The carcass weight is correlated to carcass percentage hence obtain a similar result while carcass weight influenced by the live weight of the livestock. Gunawan and Sunandari (2003) suggest that carcass weight is affected by live weight in a proportional way i.e. higher live weight results in higher carcass weight.

\section{Carcass weight and percentage of Pegagan} DUCK

Table 2 displays the tendency of probiotic and organic acid treatment effect on the increase of carcass weight and percentage. This result indicates organic acid and probiotic combined treatment provide good influence by improving the optimal nutrient absorption within livestock. Candrasih and Bidura (2001) described the use of probiotic in the ration increase the lysine analog content and aminoethyl cysteine within the digestive tract. These compounds were converted into lysine amino acid and cysteine and enhance protein retention which is important in meat formation. Faishal et al. (2013) suggested protein and amino acids intake added in the ration, suffice the amount needed by the metabolism hence increase tissue synthesis which produces more body weight as well as carcass weight. Waspodo (2001) reported that probiotic role is not only to maintain the ecosystem balance but also to provide enzyme needed for digestion of crude fiber, protein, and lipid, whereas organic acid role as acidifier of the digestive tract to maximize digestion process and nutrient absorption (Nugraha et al., 2016). Sibarandi (2014) concluded organic acid administration (citric and butyric acid) gave a positive effect of ration efficiency. Acid condition triggered absorption surface to increase on jejunum epithelial cell. Larger absorption surface area increases the digestibility of ration which in turn positively correlated with carcass weight and percentage increase and a decrease of lipid.
The treatment of probiotic and organic acid salt hence produced a relatively same percentage of commercially carcass slice with untreated duck. This similarity probably due to carcass weight and the percentage which is statistically not significant as well. Arlyanda (2010) suggested according to his result that Bacillus probiotic and lactic acid bacteria are not statistically significant to the commercial carcass slice of the broiler. Commercial slice of carcass strongly correlated to carcass weight as can be seen on Table 2 hence when it is not statistically significant towards carcass weight, the probiotic and organic acid salt also gave no significant difference towards commercial slice. Siregar and Sabrani (1982) stated that carcass parts percentage closely related to carcass weight whereas carcass weight is related to live weight.

It showed that the highest carcass slice can be found at breast part which is in accordance with Summers (2004) result. This author concluded that meat of carcass highly deposits on breast part. Parkhust and Mountney (1997) explained the meat at the breast part indicates the spread of meat on other body parts. Auvergne et al. (1991) found out live weight is the main factor which influenced breast muscle's growth. The breast muscle growth depends on ration consumption. The tendency of breast muscle builds up possibly due to enzyme availability which able to digest crude fiber, protein, and lipid (Waspodo, 2001) and probiotic ability to improve nutrient absorption. All the reason previously described trigger body weight increase as well as the cut weight which in turn increase breast part of the carcass slice.

According to Jayanata and Harianto (2011), the lactic acid bacteria (LAB) used as probiotic able to increase food digestibility of poultry, increase nutrient absorption and convert it into muscle. Bacteria also able to adhere and create a colony within the digestive tract and prevent pathogenic bacteria to grow. The LAB competes with the pathogen to absorb food and produced an anti-microbial compound which further prevent other pathogenic organisms to compete in obtaining food within the digestive tract (Fuller, 2011). Paul et al. (2007) found several factors such as pathogenic bacteria and stress condition give a negative effect on intestinal microflora and intestine epithelia. This negative condition change cell permeability which provides body resistance, causing harmful substance formation and pathogenic bacteria penetrate into the small intestine cell. The final effect of this occasion is metabolism disturbance such as nutrient digestion and absorption. Organic acid act as acidifier source creates an acidic condition in the digestive tract. The acid condition stimulates an increase of cholesterol taken from blood to form bile salt and normalize $\mathrm{pH}$ of the digestive tract (Yulianti et al., 2013). 
$\mathrm{PH}$

The value of meat quality can be determined based on meat $\mathrm{pH}$, water holding capacity (WHC), shrinkage and tenderness Average $\mathrm{pH}$ of the duck's meat is between 6.53 to 6.70. This value is higher than reported by Sari et al. (2015) i.e. $5.70-6.20$ but close to the meat $\mathrm{pH}$ obtained by Wicaksono (2016) i.e. 6.36 - 6.94. Moreover, the result indicates the effect of organic acid salt and probiotic treatment is not statistically significant on the water holding capacity, cooking shrinkage, and meat tenderness. The average value of water holding capacity (WHC) is $41.04-43.31 \%$. This value is lower than result by Huda et al. (2011) at $48.39-49.76 \%$ or by Winaztika et al. (2014) at $71.84-74.21 \%$. Cooking shrinkage average value calculated in this research is $40.29-41.99 \%$. This value is close to value by Huda et al. (2011) i.e. 37.84 $41.98 \%$ but smaller than value by Prissa et al. (2014) i.e. $30.30-32.65 \%$. The average value of meat tenderness is $5.02-5.52 \mathrm{~N}$. This value is approximately the same with data result by Tugiyanti et al. (2016) i.e. $4.83-5.44 \mathrm{~N}$ and higher to data result by Wahyuni et al. (2016) i.e. $1.42-$ $2.86 \mathrm{~N}$ of Pegagan duck.

Furthermore, inadequate doses of organic acid salts and probiotic doses of $0.2 \%$ and $0.02 \%$ respectively in the ration caused an insignificant effect on ph of meat. Mesrawati (2001) reported the addition of probiotic into ration increase useful microbe population, suppress unwanted bacteria and improve the microbial balance in the digestive tract. Digestive tract microbe produces various enzyme such as protease which assists protein hydrolysis and made it absorbed by the system easily and improve livestock performance. On the other hand, carbohydrate i.e. glucose was stored within muscle as glycogen. The less glucose being absorbed; the glycogen store will proportionally decrease.

The low glycogen stored in the muscle impacted the decrease of lactic acid formed during rigor mortis and decrease the $\mathrm{pH}$. Rigor mortis is a muscle stiffness after slaughter due to the combination of actin and myosin to form actomyosin (Suradi, 2006). According to Lyon and Buhr (2005) during post-mortem, glycolysis occurs anaerobically using muscle glycogen and initiate lactic acid formation. The $\mathrm{pH}$ decreases in post-mortem muscle highly affected by glycolysis rate. The low stored glycogen in the muscle prior to slaughter caused low lactic acid formation and also decrease the muscle pH (Arbele et al., 2001).

\section{Water Holding Capacity (WHC)}

The non-significant result in WHC is in accordance with the result by Yosi and Sandi (2014) which also obtained no statistically significant difference. Hartono et al. (2013) suggest the high value of meat $\mathrm{pH}$ inflict closed structure of meat hence $\mathrm{WHC}$ is higher whereas a low value of $\mathrm{pH}$ inflict the open structure of meat and lower the WHC of meat. Lawrie (2003) found that $\mathrm{pH}$ decrease affects the protein denaturation to increase henceforth decrease protein along with water holding capacity. In general, cooking shrinkage found is in the normal range. Law (2003) reported the cooking shrinkage has a various value between 15 to $54.5 \%$. Soeparno (2005) reported the value of cooking shrinkage is closely related to the water holding capacity. The low value of cooking shrinkage indicates a small amount of water will recede during the cooking process and nutrition loss will be low. Mulyati (2003) found out that meat with low cooking shrinkage value will have better quality compare to high cooking shrinkage value.

\section{TendeRness}

The meat tenderness value has statistically conclusion same as $\mathrm{pH}$ and WHC. Meat tenderness indeed correlated to $\mathrm{pH}$ proportionally, it got high when $\mathrm{pH}$ also is high. Prayitno et al. (2010) similarly found out that meat tenderness is affected by $\mathrm{pH}$ and WHC. The data trend observed for WHC is also the same for tenderness. One of several factors affecting the meat tenderness is protein content. The protein originated from protease activity has the potential of making the meat tender. The proteolytic enzyme made the meat tender by activating the proteolysis of protein within meat myofibril and shortening the protein fragment and made muscle fiber separate easily hence became tender (Krisnaningsih and Yulianti, 2015).

The result for $\mathrm{pH}$, WHC, cooking shrinkage and tenderness which is not significant between the treatment, suggest probiotic and organic acid salt possess the potential of substituting tetracycline in affecting the overall physical quality of meat.

\section{CONCLUSION}

Organic acid salt and probiotic made from Kumpai tembaga grass show potentials as a feed additive. Among the various treatments conducted, the addition of organic acid salt and probiotic gave no statistically significant difference in the carcass and physical meat quality. The treatments, however, tend to increase carcass weight and percentage and the commercial slice particularly breast part.

\section{ACKNOWLEDGEMENT}

The author would like to gratefully thank you to the Ministry of Research, Technology and Higher Education for research funding through Competence Grant year 2018. Also gratitude to Tri Sutrisno and Azizah Destri Hafiza for participating in this research. 


\section{AUTHORS CONTRIBUTION}

M.L. Sari and S. Sandi conceived of the presented idea. F.Yosi developed the theory and performed the computations. M.L. Sari and A.N.T. Pratama verified the analytical methods. S. Sandi encouraged M.L. Sari to investigate [a specific aspect] and supervised the findings of this work. All authors discussed the results and contributed to the final manuscript.

\section{CONFLICT OF INTEREST}

The authors whose names are listed on this journal certify that they have no affiliations with or involvement in any organization or entity with any financial interest (such as honoraria; educational grants; participation in speakers' bureaus; membership, employment, consultancies, stock ownership, or other equity interest; and expert testimony or patent-licensing arrangements), or non-financial interest (such as personal or professional relationships, affiliations, knowledge or beliefs) in the subject matter or materials discussed in this manuscript.

\section{REFERENCES}

-Abdel-Fattah SA, E1-Sanhoury MH, El-Mednay NM, AbdelAzeem F (2008). Thyroid activity, some blood constituents, organs morphology and performance of broiler chicks fed supplemental organic acids. Int. J. Poult. Sci, 7: 215-222. https://doi.org/10.3923/ijps.2008.215.222

-Abdelsamire RE, Farrell DJ (1985). Carcass Composition and Carcass Characteristics of Ducks. In: DJ Farrell dan P. Stapleton (Ed). Duck Production Science and World Practise. Univ. New Engl. Armidale.

-Aberle DE, JC Forrest, DE Gerrard, EW Mills (2001). Principles of Meat Science. Fourth Edition. W. H. Freeman and Company. San Fransisco, United States of America.

-Astuti FK, Busono W, Sjofjan O (2015). Pengaruh penambahan probiotik cair dalam pakan terhadap penampilan produksi pada ayam pedaging. JPAL, 6: 99- 104.

-Apriyanto AD, Fardiaz NL, Puspitasari., Sedamawati, Budiyanto S (1989). Analisa Pangan. PAU dan pangan Gizi. IPB Press, Bogor, Indonesia.

- Arlyanda (2010). Pengaruh Pemberian Probiotikbacillus dan Bakteri Asam Laktat Terhadap Bobot Karkas dan Irisan Komersial Ayam Broiler. BSc Thesis. Univ. Jambi, Jambi, Indonesia.

-Auvergne A, Baudonnet C, Babile R (1991). Influence of protein and methion on concentrations and body size on the growth and carcass of Muscovy ducks in the finishing stage of production. Br. Poult. Sci. 32: 353-362. https://doi. org/10.1080/00071669108417360

-Bregni C, Degrossi J, Garcia R, Lamas MC, Firenstein RY, D'aquino M (2000). Aliginate microspheres of Bacillus subtilis. Arspharma. 41: 245-248.

- Candrasih NNK. Bidura IGNG (2001). Pengaruh penggunaan cangkang kakao yang disuplementasi ragi tape dalam ransum terhadap penampilan itik Bali. Majalah Ilmiah Peternakan, 4: 67-72.
- Farida DN, Kusumaningrum HD, Wulandri N, Indrasati D (2006). Analisa laboratorium. Dapartemen ilmu dan teknologi pangan, IPB, Bogor, Indonesia.

- Faishal IJ, Djunaidi IH, Sudjarwo E (2013). Pengaruh Penambahan Tepung Kulit Manggis (Garciniamangostan L. sebagai Tambahan Pakan terhadap Karkas dan Organ Dalam Itik Mojosari Jantan. Fakultas Peternakan Universitas Brawijaya, Malang, Indonesia, Pages: 1- 10.

-Fuller R (1989). Probiotics in man and animals.J. Appl. Bacteriol. 66: 365-378. https://doi.org/10.1111/j.1365-2672.1989. tb05105.x

- Fuller R (2011). A review, probiotics in man and animals. J. Appl. Bacteriol. 66: 365-378. https://doi. org/10.1111/j.1365-2672.1989.tb05105.x

- Gunawan, Sunandari (2003). Pengaruh penggunaan probiotik dalam ransum terhadapproduktivitas.ayam. http:// peternakan.litbang.deptan.go.id/fullteks/wartazoa/ wazo133-2.pdf. Accessed on February 19.2018.

-Hartono E., Iriyanti N, Singgih SSR (2013). Penggunaan pakan fungsional terhadap daya ikat air, susut masak, dan keempukan daging ayam broiler. Fakultas Peternakan, Univ. Jenderal Soedirman, Purwokerto, Indonesia.

-Huda NP, Ahmad AAR (2011). Proximat and physicochemical properties of Peking and Muscovy duck breast and things for futher processing. J. Food Agric. 9: 82-88.

-Jayanata CE, Harianto B (2011). 28 Hari Panen Ayam Broiler. Angro Media Pustaka, Jakarta Selatan, Indonesia.

- Krisnaningsi ATN,Yuliyanti DL (2015).Pemanfaatan kombinasi ekstrak buah nanas dan papaya untuk meningkatkan kualitas fisik daging itik petelur afkir. Buana Sains, 15: 1-6.

-Lawrie RA (2003). Meatsciences. The $6^{\text {th }}$ ed. A. Paraksi dan A. Yhuda (Eds.). Penerbit Universitas Indonesia, Jakarta, Indonesia.

-Lyon CE, Buhr RJ (2005). Biochemical basis of meet texture. Poult. Meet Sci., 25.

-MulyaniTD,MahfudzLD,Sukamto B (2013).Efekpenambahan asam sitrat dalam ransum terhadap pertambahan bobot badan dan karkas itik jantan lokal periode grower. Anim. Agric. J. 2: 11-22.

- Marlina N,Zubaidah E, Sutrisno A (2015). Pengaruh pemberian antibiotika saat budidaya terhadap keberadaan residu pada daging dan hati ayam pedaging dari peternakan rakyat. J. Ilmu-Ilmu Peternakan.25: 10-19. https://doi.org/10.21776/ ub.jiip.2015.025.02.02

- Mulyati (2003). Pengaruh Penggunaan Bungkil Biji Karet yang di Fermentasi dengan Ragi Tempe dan Oncom dalam Ransum Terhadap Kualias Daging Ayam Broiler. MSc Thesis. Fakultas Peternakan, Univ. Diponegoro, Semarang, Indonesia.

- Mesrawati (2001). Studi Tentang Penambahan Probiotik Terhadap Penampilan Ayam kedu yang Mendapat Ransum Berbeda Level dan Serat Kasar. MSc Thesis. Fakultas Peternakan, Univ. Diponegoro, Semarang, Indonesia.

- National Research Council. 1994. Nutrient Requirements of Poultry: Ninth Revised Edition, 1994. Washington, DC: The National Academies Press. https://doi.org/10.17226/2114

- Natsir MH, Sjofjan O (2008). Pengaruh penggunaan kombinasi asam sitrat dan asam laktat cair dan terenkapsulasi sebagai aditif pakan terhadap penampilan produksi ayam pedaging. Seminar Nasional Teknologi Peternakan dan Veteriner. pp. $636-640$.

- Natsir MH (2012). Pengaruh penggunaan beberapa jenis enkapsulasi pada asam laktat terenkapsulasi sebagai acidifier 
terhadap daya cerna protein dan energi metabolis ayam pedaging. J. Ternak Tropika, 6: 13-17.

- Nugraha TS, Wahyuni HI, Suthama N (2016). Pengaruh penambahan asam sitrat dalam ransum sebagai acidifier terhadap kecernaan protein dan bobot badan akhir pada itik jantan lokal. Agromedia, 2: 49-53.

- Negara W (2009). Kajian Produksi Garam Asam Organik dari Silase Ransum Komplit Sebagai Pemacu Pertumbuhan pada Ayam Broiler yang Ditantang Salmonella typhimmurium. MSc Thesis, IPB, Bogor, Indonesia.

- Sihite M, Pakpahan P (2015). Pengaruh Pemberian Probiotik Campuran Streptococcusthermophillus dan BacillusCereus Dalam Air Minum Terhadap Bobot Badan dan Pertambahan Bobot Badan Mingguan Itik Magelang Jantan. Fakultas Peternakan, Universitas Padjadjaran, Sumedang, Indonesia.

- Steel RGD, dan JH Torrie (1993). Prinsip dan Prosedur Statistika. Terjemahan Bambang Sumantri. Gramedia. Jakarta.

- Owings W J, Reynolds DL, Hasiakand RJ. Ferket R (1990). Influence of dietary supplementation with Streptococcus faecium M-74 on broiler body weight, feed conversion, carcass characteristics and intestinal microbial colonization. Poult. Sci. 69: 1257-1264. https://doi. org/10.3382/ps.0691257

-Sari ML, Lubis FNL, Dewi K (2015). Pengaruh pemberian probiotik dan tepung kunyit (Curcuma domesticaVal) dalam ransum terhadap $\mathrm{pH}$, warna dan aroma daging itik Pegagan. Jurnal Peternakan Sriwijaya, 4: 47-53. https://doi. org/10.33230/JPS.4.1.2015.2299

- Sandi S, Yosi F, Sari LM (2017). Potensi silase hijauan rawa sebagai probiotik dan acidifier pengganti antibiotik untuk meningkatkan produktivitas ternak itik Pegagan Sumatera Selatan. Laporan Penelitian Hibah Kompetensi, Universitas Sriwijaya, Indralaya, Indonesia.

- Soeparno (2005). Ilmu dan Teknologi Daging. $4^{\text {th }}$ Ed. Gadjah Mada University Press, Yogyakarta, Indonesia.

- Soeparno (2009). Ilmu dan Teknologi Daging. $5^{\text {th }}$ Ed. Gadjah Mada University Press, Yogyakarta, Indonesia.

- Soltan MA (2008). Effect of organic acid supplementation on egg production, egg quality, and some blood serum parameters in laying hens. Int. J. Poult. Sci., 7: 613-621. https://doi.org/10.3923/ijps.2008.613.621

- Sibarandi YD (2014). Persentase karkas dan non karkas serta lemak abdominal ayam broiler yang diberi acidifier asam sitrat dalam pakan doble step down. J. Agric., 3: 273-280.

- Siregar, Sabrani (1982). Teknik Beternak Ayam Pedaging di Indonesia. $2^{\text {nd }}$ Ed. Margie Group, Jakarta, Indonesia.

- Singh S, Sanjay S, Neelam T, Nitesh K, Ritu P (2014). Antibiotic residues: a global challenge. Int. J. Pharma. Sci. Pharma. Sci. Monitor, 5: 184-197

- Summers JD (2004). Broiler Carcass Composition. Poult. Ind. Counc. Res. Educ. Guelph, Kanada.

- Srigandono B (1997). Ilmu Unggas Air. Gadjah Mada Univ. Press, Yogyakarta, Indonesia.

- Sudiyono, Purwatri TH (2007). Pengaruh penambahan enzim dalam ransum terhadap persentase kaskas dan bagianbagian karkas itik lokal jantan. J. Indon. Trop. Anim. Agric. 32: $270-277$

-Sukirmansyah, Daud M, Latif H (2016). Evaluasi produksi dan persentase karkas itik peking dengan pemberian pakan fermentasi probiotik. Jurnal Ilmiah Mahasiswa Pertanian Unsyiah, 1: 719-730.

-Suradi (2006). Performa Mencit Putih (Mus musculus) dengan Penambahan Ekstrak Kunyit (Curcuma demosticaVal) dalam Air Minum. BSc Thesis. Fakultas Peternakan, Institut Pertanian Bogor, Bogor, Indonesia.

- Sastroamidjojo SM (1990). Peternakan Umum. CV. Yasaguna, Yogyakarta, Indonesia.

- Parkhurst CR, Mountney GJ (1997). Poultry Meat and Egg Production Vantr and Reinhold. New York., USA.

- Prissa E, Suswoyo I, Wasito S (2014). Susut masak dan pH daging itik lokal afkir berdasarkan sistem pemeliharaan dan lokasi yang berbeda. Jurnal Ilmiah Peternakan, 2: 221-226.

- Puspani E, Roni NGK, Bidura IGNG (2016). Suplementasi probiotik dalam ransum basal untuk meningkatkan penampilan serta menekan jumlah lemak abdomen dan gas amonia ekskreta itik. Majalah Ilmiah Peternakan, 9: 34-40

- Paul SK, Halder G, Mondal MK, Samanta G (2007). Effect of organic acids alton the performance and gut health of broiler chicken. J. Poult. Sci., 44: 389-395. https://doi.org/10.2141/ jpsa.44.389

- Prayitno AH, Suryanto E, Zuprizal (2010). Physical and sensory quality of meat of broiler chicken fed with the addition of virgin coconut oil waste. Buletin Peternakan, 34: 55-63. https://doi.org/10.21059/buletinpeternak.v34i1.107

- Tugiyanti E, Hari IS, Setianto NA, Susanti E, Mastuti S (2016). Pengaruh pemberian tepung daun sukun ke dalam pakan terhadap kualitas daging itik Tegal jantan umur 9 minggu. Seminar Nasional Peternakan, 2: 174-182.

-Waspodo IS (2001).Agar Probiotik Menyehatkan Saluran Cerna. Internet. http://www.kompas.com /kompascetak/0411/06/ Jendela/1 36780.htm. Accessed on April 4.2018.

-Wahyuni D, Arisuteja S, Sandi S, Yosi F (2016). Pengaruh suplementasi probiotik dalam ransum terhadap kualitas fisik daging itik. Sains Peternakan, 14: 50-56. https://doi. org/10.20961/sainspet.14.2.50-56

-Winaztika R, Wasito S, Suswoyo I (2014). Daya ikat air dan keempukan daging itik mojosari afkir berdasarkan sistem dan lokasi pemeliharaan. Jurnal Ilmiah Peternakan, 2: 58-64.

-Wicaksono AD (2016). Pengaruh Sistem Pemeliharaan Dan Waktu Maturasi Terhadap Kualitas Daging Itik (Anas Sp.) Bagian Dada. BSc Thesis. Fakultas Peternakan, Universitas Hasanudin, Makssar, Indonesia.

-Yulianti W, Murningsi W, Ismadi VDYB (2013). Pengaruh penambahan sari jeruk nipis (Citrusaurantifolia) dalam pakan terhadap profil lemak darah itik magelang jantan. Animal agiculture Journal, 2: 51-58

-Yosi F, Sandi S (2014). Meat Quality, Blood Profile, and Fecal Ammonia Concentration of broiler supplemented with Liquid Smoke. Media Peternakan, 37: 169-174. https://doi. org/10.5398/medpet.2014.37.3.169 